\title{
Mapping of Livelihood Capitals for Technological Interventions in Elephant Foot Yam and Banana Cultivation in Andhra Pradesh
}

\author{
Sheela Immanuel, D. Jaganathan*, A.V. V. Koundinya, P. Prakash, \\ P. Sethuraman Sivakumar, H. Kesava Kumar and R. Muthuraj \\ ICAR-Central Tuber Crops Research Institute, Sreekariyam, \\ Thiruvananthapuram-695 017, India \\ *Corresponding author
}

\section{A B S T R A C T}

\begin{tabular}{|l|}
\hline K e y w o r d s \\
$\begin{array}{l}\text { Elephant foot yam, } \\
\text { Banana, Rural } \\
\text { Sustainable } \\
\text { Livelihood Index, } \\
\text { Technology, } \\
\text { Interventions, } \\
\text { Mapping }\end{array}$ \\
\hline Article Info \\
\hline $\begin{array}{l}\text { Accepted: } \\
\text { 26 July 2020 } \\
\text { Available Online: } \\
\text { 10 August } 2020\end{array}$ \\
\hline
\end{tabular}

Mapping of livelihood capitals was done among 60 elephant foot yam and 60 banana growing farmers using snow ball sampling in East Godavari and West Godavari districts of Andhra Pradesh. Data were collected using PRA tools, interview schedule and focus group discussions during August 2018 to January 2019. Rural Sustainable Livelihood Index (RSLI) was arrived by using the DFID methodology. The family size and farming experience of elephant foot yam and banana growers differ significantly at $10 \%$ and one per cent respectively. The yield and cost of cultivation for banana was higher than the elephant foot yam and significant differences were observed at one per cent level. The net profit realized from the two crops were, ₹ 1.58 lakhs for banana and ₹ 1.62 lakhs for elephant foot yam. Under human capital, the index was higher for education (55) and health (57) for elephant foot yam growers whereas, for banana growers farming experience (73) and knowledge (62) was more. Physical capital index was more or less similar for both the growers. Social capital index was more (66) for banana growers. The financial capital index was more for banana growers (69) and the natural capital index was 70 for both the farmers. The RSLI for banana growers was slightly higher (69) than the elephant foot yam growers (66). Similarities between capitals of both the growers are in the decreasing order with respect to physical, natural, financial, social and human capitals. The vulnerability factors as reported were price fluctuation, crop failure due to weather aberrations and increased labour cost. Non availability of skilled labourers, non availability of quality planting materials of improved varieties, price fluctuation, involvement of middlemen in the market, weather aberrations and lack of marketing facilities were the major constraints.

\section{Introduction}

Elephant foot yam is an underground stem tuber and its cultivation is more or less limited to India, Philippines, Indonesia, Sri Lanka and South East Asia. It has high dry matter production capability per unit area than most of the other vegetables. It is a popular tuber crop and is grown as a vegetable in many parts of India, especially South, East and North Eastern states in an area of 30,000 ha with a production of 7.74 lakh tonnes (GoI, 
2018). It thrives well under warm humid climate. It grows well on a variety of soils but a well drained sandy loam or sandy clay loam soil with a neutral soil reaction is ideally suitable for the crop. It undergoes a dormancy period of 45 to 60 days. By taking advantage of this, farmers plant them during February to March so that setts would sprout with the pre monsoon showers.

It can be grown as an intercrop in coconut, arecanut, rubber, banana and coffee plantations. It becomes ready for harvest in about 8-9 months. Gajendra, Sree Padma and Sree Athira are the popular improved varieties grown by the farmers in India.

Elephant foot yam plays an important role in food and nutrition security for the global population especially the small and marginal famers. Elephant foot yam is one of the major tuber crops grown in Andhra Pradesh for livelihood security of the farmers in an area of 3540 ha with a production of 2.0 lakh tonnes (GoAP, 2018). Similarly, banana is an important commercial crop grown in an area of 88,170 ha with a production of 46.72 lakh tonnes in Andhra Pradesh (GoAP, 2018). Farmers have their own livelihood strategies to cope up with the environment and to sustain their living. Livelihood assessment of the elephant foot yam growers and comparing it with another important crop in the study area i.e. banana growers will help to identify the different capital assets possessed by the growers and their contribution to their livelihood. Livelihoods are 'means of making a living', the various activities and resources that allow people to live (FAO, 2007). To improve the livelihood status of the growers, the concept of sustainable livelihoods is increasingly gaining importance in research and development initiatives for poverty alleviation and rural agriculture development (Chambers, 1987; Ashley, 2000).
Livelihood can be defined as a measure of the set of actions taken by people within their capacity and capitals to make a living by maintaining highly diverse portfolio of activities, while livelihood capitals cover natural, physical, human, social and financial resources that are critical to the survival of people in response to stresses and shocks while not compromising the natural resource base (Scoones, 1998; Ellis, 2000; Ansoms and McKay, 2010; Mutenje et al., 2010). Livelihood capitals viz., human, financial, social, natural and physical capitals and household structure, labour quality and ecological policies are the major drivers of farmers' choice of livelihood strategy (Iiyama et al., 2008; Mutenje et al., 2010; Angelson et al., 2014; Peng et al., 2017). The Sustainable Livelihood Approach (SLA)/ Sustainable Livelihood Framework (SLF) assumes that people's livelihood is a set of five livelihood capitals or assets (Sayer and Campbell 2003). Elephant foot yam and banana are the two important commercial crops which provide livelihood support to the farmers of East Godavari and West Godavari districts of Andhra Pradesh. Thus, it is important to map the different livelihood capitals of both the farmers to formulate suitable technological interventions to enhance the livelihood status of the farmers. With this background, the study was conducted with the objectives, to investigate the socioeconomic characteristics of elephant foot yam and banana growers, to map the different sustainable livelihood capitals of elephant foot yam and banana growers and to formulate suitable technological interventions to enhance farmers' capabilities for sustainable livelihood security.

\section{Materials and Methods}

The study was conducted in East Godavari and West Godavari districts of Andhra Pradesh which are the major producers of 
elephant foot yam and banana in Andhra Pradesh. The data collection for mapping of livelihood capitals was done during August 2018 to January 2019. From each district, three villages were selected randomly and from each village ten elephant foot yam and ten banana growers were selected using snowball sampling and thus the total sample was 120 .

The farmers deriving more than $50 \%$ of their income from each crop viz., elephant foot yam and banana were selected as respondents. Data were collected using PRA tools, structured interview schedule and focus group discussion. The DFID's livelihood framework (DFID, 2000) was adopted (Fig. 1) to assess the different capitals possessed by the elephant foot yam and banana growers.

The conceptual framework of Department for International Development (DFID) provides attention to measured changes in the different factors, which contribute to livelihoods especially human, social, financial, physical and natural assets (DFID, 2000). The sustainable livelihoods framework presents the main factors that affect the sources of people's livelihoods and also make typical relationship between them. Livelihood capital index was worked out for each capital using the formula.

Capital Index = Actual score/Maximum obtainable score x 100

Actual score is the score obtained by the respondent under the each capital.

Rural sustainable livelihood index $=\mathrm{HCI}+\mathrm{PCI}$ $+\mathrm{SCI}+\mathrm{FCI}+\mathrm{NCI} / 5$

where, HCI: Human Capital Index, PCI: Physical Capital Index, SCI: Social Capital Index,
FCI: Financial Capital Index and NCI: Natural Capital Index

\section{Results and Discussion}

\section{Profile of districts}

The socioeconomic, agroclimatic and edaphic particulars of East Godavari and West Godavari districts (GoAP, 2018) are given in Table 1. Both the districts come under the tropical climate. The livelihood security of the people in both the districts is mainly dependent on agricultural and allied activities as they are evident from the details given in Table 1.

\section{Socioeconomic characteristics of elephant foot yam and banana growers}

It is seen from Table 2 that the average age of the farmers was 46 years for elephant foot yam growers whereas it was 48 years for banana growers and there was no significant difference. The level of education was more or less similar for both the farmers. The number of family members in a household was five for elephant foot yam growers and four for banana growers. In India, the average household size for all areas stands at 4.3, while it is 4.5 for rural and 4.1 for the urban areas. (Census India.gov.in, GOI, 2011). In the study area, the family size was almost same as that of the national average. The total farm size was 5.25 ha for elephant foot yam growers and 5.47 ha for banana growers. The area for cultivation of elephant foot yam was more (1.90 ha) which was not significant at 1 percent level in comparison to banana area under cultivation (1.80 ha). Farming experience was more for banana farmers (21.15 years) which showed that banana is a traditional crop which is being cultivated since many years for their food and livelihood security. Similar findings were reported by Jaganathan et al., (2019). 
Costs and returns in elephant foot yam and banana cultivation

The costs and returns in elephant foot yam and banana cultivation is given in Table 3 . The average yield of elephant foot yam (38 $t$ $\left.h a^{-1}\right)$ was lesser than the yield of banana (44 t $\mathrm{ha}^{-1}$ ) which was significant at 1 percent level. The yield and cost of cultivation for banana were higher than the elephant foot yam and significant differences were observed at $1 \%$ level. There was no significant difference with respect to cost of production and net profits realized from elephant foot yam and banana. The cost of cultivation of banana was ₹ 2.20 lakh whereas, for the elephant foot yam it was ₹ 1.76 lakh. The net profit realized from the two crops were, ₹ 1.58 lakh for banana and ₹ 1.62 lakh for elephant foot yam. On an average, the elephant foot yam farmers realized $2.7 \%$ higher net profits than the banana growers.

\section{Mapping of livelihood capitals Index}

Livelihood capitals viz., human, physical, social, financial and natural indices of elephant foot yam and banana growers are discussed below.

\section{Human capital index}

Human capital includes education level of the growers, training undergone, labour availability, health facilities and experience of the growers. It helps people to pursue livelihood strategies to achieve their goals. At a household level, human capital is the factor of the number and quality of labour available; this varies according to household size, skill levels, leadership potential, health status, etc. It is a key factor within the livelihood framework for the reason that all other capitals are partly depend on it for the sustainability (Sayer and Campbell, 2003).
It is observed from the Table 4 that the education index of elephant foot yam growers (55) was more than the banana growers (48). Similar trend was observed with regard to training index. The reason could be that more number of trainings were organised by the department for banana cultivation than elephant foot yam cultivation. As Lynton and Pareek (1990) stated that training consists largely of well organized opportunities for participants to acquire necessary understanding and skill. Hence efforts need to be put to organize training programmes for elephant foot yam growers. Labour availability was same for both the farmers as both crops are having same duration for giving economic returns. Knowledge level was more for banana growers which may be due to the trainings they had attended. The farming experience was more for banana growers as they were involved in traditional farming over the years. Health facilities were more for elephant foot yam growers. The overall human capital index was more for banana growers (66) than elephant foot yam growers (50). Similar findings were reported by Sheela Immanuel et al., 2019 and Jaganathan et al., 2019.

\section{Physical capital index}

Physical capital is the basic infrastructure and an indicator for the development status of the villages. It includes transport facilities, housing type, drinking water facilities, electricity and cooking fuel available to the growers. Jonathan (2000) stated that infrastructure is commonly a public good that is used without direct payment, consisting of changes to the physical environment that help people to meet their basic needs and to be more productive.

It is inferred from the Table 5 that all the villages were electrified which indicates the progress witnessed by the villages in study 
areas in Andhra Pradesh. Transport and housing facilities were more for banana growers than elephant foot yam growers. Whereas, drinking water and fuel facilities were more for elephant foot yam growers than banana growers. The overall physical capital index was more for banana growers (85) than elephant foot yam growers (82).

\section{Social capital index}

Social capital has direct link with the development of the society and the livelihood of the people. Social capital refers to social resources including informal networks, membership and relationships of formalised groups and trust that facilitate cooperation (Clark and Carney 2008, Sayer and Campbell 2003). The components under social capital are relationship within the communities, membership in organisations, access to society, access to agricultural information and communication facilities available in the village. Social capital is the most important resource available in the rural communities as they have a strong societal tie up.

From the Table 6 , it is observed that social capital index was more for banana growers (66) than elephant foot yam growers (61). Membership in organisations was same for both the farmers. However, social relationship, access to organisations, access to agricultural information and communication facilities were more for banana growers. This could be due to more number of meetings/ trainings organized by department/banana growers association. Moreover, banana was a major commercial crop and farmers were given more information through various TOT programmes including social media.

\section{Financial capital index}

Financial capital includes household income, access to credit, savings, and the borrowed capital. Financial capital is very crucial for growth and development in a society. Farming community is largely supported by financial institutions for enhancing their farm activities. The Government is also improving the financial capacity of the farmers by providing them subsidies, loans and grants. Various farmers' oriented schemes are operated for the welfare of the farmers. Financial capital enables people to opt for other livelihood strategies.

It is clear from the Table 7 that the household income, savings and borrowed capital were more for banana growers when compared to elephant foot yam growers. Credit facilities index was slightly more for elephant foot yam growers (70) than banana growers (67). The overall financial capital index was more for banana growers (69) than elephant foot yam growers (67). Access to agricultural credit is an important element in empowerment process (Hedden-Dunkhorst et al., 2001). Poor farmers as well as the medium farmers usually avail loan of $40 \%$ towards meeting any calamities faced in their agricultural and livestock sectors. (Swathi Lekshmi, 2008).

\section{Natural capital index}

Natural capital includes the land area owned by the growers, ownership status of cultivable land, type of land and the number of crops grown by the farmer. Most of the agricultural activities depend on the natural capital. If the natural resources are conducive and favourable, it will contribute to the agriculture development in the rural areas.

It is revealed from the Table 8 that the index for ownership of land was more for banana growers (94) as compared to elephant foot yam growers (88). The index for area of land possessed by elephant foot yam growers was 56 whereas it was 53 for banana growers. 
Table.1 District profile of East Godavari and West Godavari

\begin{tabular}{|c|c|c|c|}
\hline S.No. & Particulars & East Godavari & West Godavari \\
\hline 1 & Latitude and Longitude & $17.3213^{\circ} \mathrm{N}, 82.0407^{\circ} \mathrm{E}$ & $16.9174^{\circ} \mathrm{N}, 81.3399^{\circ} \mathrm{E}$ \\
\hline 2 & Area (Sq.km) & 12805 & 7742 \\
\hline 3 & Population(Lakhs) & 52.86 & 39.36 \\
\hline 4 & Mandals(Nos.) & 64 & 48 \\
\hline 5 & Villages(Nos.) & 1681 & 881 \\
\hline 6 & Net Sown Area ('000 ha) & 418.1 & 432.3 \\
\hline 7 & Gross Cropped Area ('000 ha) & 766.5 & 699.8 \\
\hline 8 & Cropping Intensity (\%) & 183.3 & 161.9 \\
\hline 9 & Net Irrigated Area ('000 ha) & 277.8 & 364.5 \\
\hline 10 & Rainfall (mm) & $1000-1200$ & $1000-1200$ \\
\hline 11 & Temperature $\left({ }^{\circ} \mathrm{C}\right)$ & $\begin{array}{l}32 \text { to } 36 \\
23 \text { to } 24\end{array}$ & $\begin{array}{l}32 \text { to } 36 \\
23 \text { to } 24\end{array}$ \\
\hline 12 & Soil types & $\begin{array}{c}\text { Clay loam, Red sandy } \\
\text { loam and Sandy clay } \\
\text { loam }\end{array}$ & $\begin{array}{l}\text { Alluvial, Sandy alluvial, } \\
\text { Deltaic alluvial, Coastal } \\
\text { sandy loam }\end{array}$ \\
\hline 13 & Major horticultural crops & $\begin{array}{l}\text { Coconut, banana, } \\
\text { cashewnut, tuber crops, } \\
\text { vegetables, mango }\end{array}$ & $\begin{array}{l}\text { Coconut, banana, } \\
\text { cashewnut, tuber crops, } \\
\text { vegetables, mango }\end{array}$ \\
\hline 14 & Literacy $(\%)$ & 80.78 & 74.63 \\
\hline
\end{tabular}

Table.2 Socioeconomic characteristics of Elephant Foot Yam (EYF) and banana growers

\begin{tabular}{|l|c|c|c|}
\hline Characteristics & EFY (n=60) & Banana (n=60) & Difference \\
\hline Age of respondent (years) & 46.3 & 48.3 & 2.00 \\
\hline Level of education (years) & 6.71 & 7.15 & 0.43 \\
\hline Household size (number) & 4.81 & 4.16 & $0.65^{*}$ \\
\hline Total farm size (ha) & 5.25 & 5.47 & 0.22 \\
\hline Area for cultivation (ha) & 1.90 & 1.80 & 0.10 \\
\hline Farming experience (years) & 15.25 & 21.15 & $5.9^{* * *}$ \\
\hline
\end{tabular}

*** significant at $1 \%$ level, *significant at $10 \%$ level

Table.3 Costs and returns in elephant foot yam and banana cultivation

\begin{tabular}{|l|c|c|c|c|}
\hline Particulars & $\begin{array}{c}\text { EFY } \\
(\mathbf{n = 6 0})\end{array}$ & $\begin{array}{c}\text { Banana } \\
(\mathbf{n = 6 0})\end{array}$ & Difference & $\begin{array}{c}\text { \% } \\
\text { increase }\end{array}$ \\
\hline Yield $\left(\mathbf{t} \mathbf{~ h a}^{-\mathbf{1}}\right)$ & 38.0 & 44.0 & $6^{* * * *}$ & 13.7 \\
\hline Cost of cultivation $\left(\boldsymbol{₹} \mathbf{~ h a}^{-\mathbf{1}}\right)$ & 175875.0 & 220458.0 & $44583 * * *$ & 20.2 \\
\hline Cost of production $\left(\boldsymbol{₹}\right.$ quintal $\left.^{-\mathbf{1}}\right)$ & 473.9 & 513.8 & 40 & 7.8 \\
\hline Net profit $\left(\boldsymbol{₹} \mathbf{h a}^{-\mathbf{1}}\right)$ & 162065.0 & 157773.0 & 4292 & 2.7 \\
\hline
\end{tabular}

$* * *$ Significant at $1 \%$ level 
Table.4 Human capital index of elephant foot yam and banana growers

\begin{tabular}{|l|c|c|}
\hline Parameters & EFY growers $\mathbf{( n = 6 0 )}$ & Banana growers $(\mathbf{n = 6 0})$ \\
\hline Education & 55 & 48 \\
\hline Training & 27 & 37 \\
\hline Labour & 51 & 51 \\
\hline Health & 57 & 53 \\
\hline Experience in farming & 51 & 73 \\
\hline Knowledge & 57 & 62 \\
\hline Human Capital Index & 50 & 54 \\
\hline
\end{tabular}

Table.5 Physical capital index of elephant foot yam and banana growers

\begin{tabular}{|l|c|c|}
\hline Parameters & EFY growers $(\mathbf{n = 6 0})$ & Banana growers $(\mathbf{n = 6 0})$ \\
\hline Transport facilities & 60 & 71 \\
\hline Housing type & 74 & 81 \\
\hline Drinking water facilities & 78 & 77 \\
\hline Fuel resources & 98 & 95 \\
\hline Electricity facilities & 100 & 100 \\
\hline Physical Capital Index & 82 & 85 \\
\hline
\end{tabular}

Table.6 Social capital index of elephant foot yam and banana growers

\begin{tabular}{|l|c|c|}
\hline Parameters & EFY growers $(\mathbf{n = 6 0})$ & $\begin{array}{c}\text { Banana growers } \\
(\mathbf{n = 6 0})\end{array}$ \\
\hline Social relationship & 58 & 63 \\
\hline Membership in organisation & 65 & 65 \\
\hline Access to organization & 64 & 70 \\
\hline Access to agricultural information & 57 & 60 \\
\hline Communication facilities & 63 & 71 \\
\hline Social Capital Index & 61 & 66 \\
\hline
\end{tabular}

Table.7 Financial capital index of elephant foot yam and banana growers

\begin{tabular}{|l|c|c|}
\hline Parameters & EFY growers $(\mathbf{n = 6 0})$ & Banana growers $(\mathbf{n = 6 0})$ \\
\hline Household income & 66 & 69 \\
\hline Credit facilities & 70 & 67 \\
\hline Savings & 60 & 66 \\
\hline Borrowed capital & 72 & 74 \\
\hline Financial Capital Index & 67 & 69 \\
\hline
\end{tabular}


Table.8 Natural capital index of elephant foot yam and banana growers

\begin{tabular}{|l|c|c|}
\hline Parameters & EFY growers $(\mathbf{n}=\mathbf{6 0})$ & Banana growers $(\mathbf{n = 6 0})$ \\
\hline Area of land & 56 & 53 \\
\hline Ownership of land & 88 & 94 \\
\hline Crops grown & 66 & 55 \\
\hline Type of land & 100 & 100 \\
\hline Natural Capital Index & 70 & 70 \\
\hline
\end{tabular}

Table.9 Comparison of the different capitals between elephant foot yam and banana growers

\begin{tabular}{|l|c|c|c|}
\hline Capitals & EFY growers (n=60) & Banana growers (n=60) & Ranking \\
\hline Human Capital & 50 & 54 & V \\
\hline Physical Capital & 82 & 85 & I \\
\hline Social Capital & 61 & 66 & IV \\
\hline Financial Capital & 67 & 69 & III \\
\hline Natural Capital & 70 & 70 & II \\
\hline Rural Sustainable Livelihood Index & 66 & 69 & \\
\hline \multicolumn{2}{|c|}{ Physical $>$ Natural >Financial >Social >Human } \\
\hline
\end{tabular}

Fig.1 Sustainable Livelihood Framework by DFID, 2000

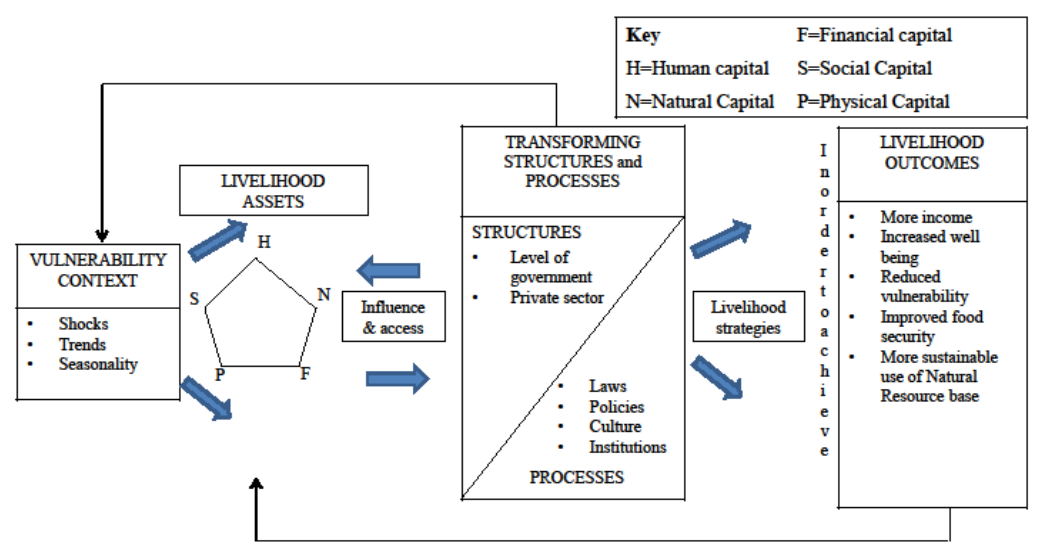

Fig.2 Comparison among livelihood capitals of elephant foot yam and banana growers

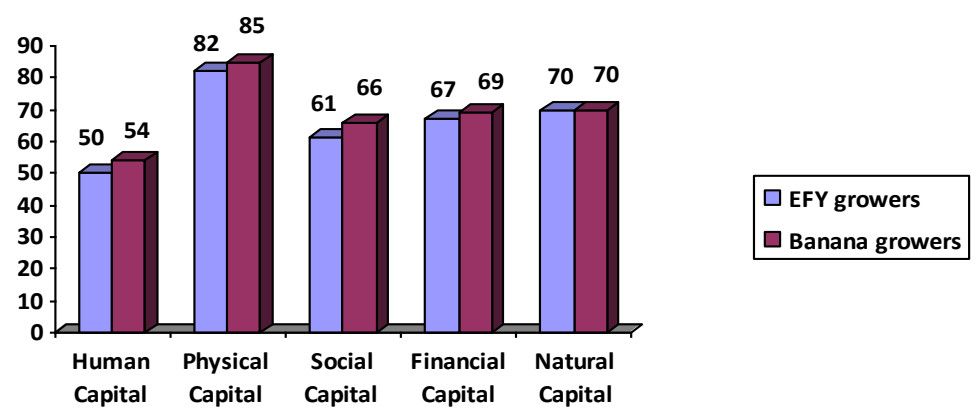


The index for type of land was same for both the farmers. The natural capital index was 70 for both the farmers. Access to natural capital may facilitate improvements to other livelihood assets such as financial capital for income generation through productive means (Pereira and Shackleton, 2006). Cropping systems viz., incorporation of oilseed and pulses for ensuring livelihood security of the farmers by producing necessary household items and generating more employment during lean period was adopted by farmers (Sharma et al., 2019).

\section{Rural sustainable livelihood index}

The rural sustainable livelihood index for banana growers was slightly higher (69) than the elephant foot yam growers (66). Physical and natural index was more than natural capital index in both the cases. Similar findings were reported by Sheela Immanuel et al., 2017 and Jaganathan et al., 2019. In the order of merit, human capital index was less among the all the capitals (Table 9). The association or similarities of different capitals between elephant foot yam and banana growers are given in Fig. 2. Similarities between capitals of elephant foot yam and banana growers are in the decreasing order with respect to physical, natural, financial, social and human capitals.

Sheela Immanuel et al., 2019 and Jaganathan et al., 2019 reported that physical and natural capitals were higher while those for social, human and financial capitals were lower among cassava growers in Tamil Nadu and sweet potato growers in Karnataka respectively. Major sources of livelihood as reported by both the farmers were, agriculture, employment in private sector and petty business. The vulnerability factors were price fluctuation, climatic variations and increased labour cost. The trends observed were high input cost, climate change and labour shortage. The constraints reported by the elephant foot yam and banana farmers were ranked based on mean score. Non availability of skilled labour was ranked first with a mean score of 2.63 out of maximum score of 3. The other constraints reported by the elephant foot yam growers were lack of quality planting materials (2.48), price fluctuation (2.33), involvement of middlemen in the market (2.23), lodging of crop due to weather aberrations (2.12) and lack of marketing facilities (2.07). Non availability of quality planting materials (2.53), non availability of skilled labour (2.48), incidence of pests and diseases (2.43), crop damage due to weather aberrations (2.38), price fluctuation (2.30) and involvement of middlemen in the market (2.27) were perceived as major constraints in banana cultivation.

\section{Strategies for technological interventions for enhancing livelihood capitals}

Mapping of livelihood capitals revealed that elephant foot yam and banana being tropical crops with high yielding potential and nutritional qualities contribute significantly towards livelihood security of the growers. Ensuring availability of good quality planting materials would greatly help in enhancing the productivity and profitability of both elephant foot yam and banana farming. Tuber crops based cropping/farming system may be adopted in large scale keeping in view of the demand for the produce in domestic and international market. Sequential cropping of elephant foot yam followed by cereals, banana, pulses and vegetables etc. may be adopted to maintain the soil fertility to get better yield and which in turn will help in food and nutritional security. Formation of farmer producer organizations (FPOs) with the help of department of horticulture and other stakeholders would ensure remunerative price for their produce through proper 
marketing and value addition. The rural sustainable livelihood analysis indicated the relative importance and the role of each capital for the development of farming. Reduction in human and financial capital would inhibit the development of elephant foot yam and banana growers. So, more opportunities need to be given to the farmers to improve their knowledge and skill through capacity building programmes. To improve their credit, more support to be given to them through strengthening of rural banks/cooperative organizations. This would enable improvement of other capitals, thereby contributing to the improvement of the livelihood of elephant foot yam and banana growers.

In conclusion the mapping of livelihood capitals of elephant foot yam and banana growers was done using a sustainable livelihood framework. Elephant foot yam and banana are the two important commercial crops which are grown by the farmers for their livelihood security. Livelihood capitals of both the growers can further be improved by technological interventions viz., supply of quality planting materials of improved varieties, capacity building of farmers to adopt improved technologies including cropping system approaches, formation of farmers producers organizations and facilitating marketing arrangements. In addition, among all the capitals, financial capital is the main string in the chain of growth and development for which interventions in the form of financial packages viz., credit/subsidy/insurance need to be given to the farmers for enhancing their financial status. Technological interventions would definitely lead to large scale adoption of scientific methods of cultivation for better production, productivity and farm income in the long run. The livelihood status of elephant foot yam growers is more or less similar to banana growers hence, elephant foot yam cultivation could also be popularized in similar locations without compromising their livelihood status.

\section{References}

Angelsen, A., Jagger, P., Babigumira, R., Belcher, B., Hogarth, N. J., Bauch, S., Rner, J. B., Smith, C. H., Wunder, S. 2014. Environmental income and rural livelihoods: A global comparative analysis. World Dev. 21: 234-252

Ansoms, A., Mckay, A. A. 2010. A quantitative analysis of poverty and livelihood profiles: The case of rural Rwanda. Food Policy 35: 584-598

Ashley, 2000. Applying livelihood approaches to natural resources management initiatives: Experiences in Namibia and Kenya. Working Paper 134; Overseas Development Institute, U.K.

Chambers, R. 1987. Sustainable livelihoods, environment and development: putting poor rural people first. IDS Discussion Paper no. 240, University of Sussex, Institute

Clark and Carney 2008. Sustainable rural livelihoods: Practical concepts for the $21^{\text {st }}$ century. Institute of Development Studies.

DFID, 2000. Sustainable livelihoods-current thinking and practice. London: Department for International Development.

Ellis, F. 2000.The determinants of rural livelihood diversification in developing countries. J. Agric. Econ. 51:289-302.

FAO. 2007. Food and Agricultural Organization of the United Nations. FAO Statistics, Rome, Italy.

GoI. 2018. Agricultural statistics at a glance2018, Department of Agriculture, cooperation and farmers welfare, Ministry of Agriculture and Farmers' Welfare, New Delhi 
GOI. 2011. Government of India. www.censusindia.gov.in

GoAP. 2018. Government of Andhra Pradesh. www.andhrapradesh.gov.in

Hedden-dunkhorst, B., Mathonzi, T. and Mphahlele, E. R. 2001. Institutional Transformation of small-scale irrigation farming in South Africa. Agrekon 40(1): 60-75.

Iiyama, M., Kariuki, P., Kristjanson, P., Kaitibie, S. and Maitima, J. 2008. Livelihood diversification strategies, incomes and soil management strategies: A case study from Kerio Valley, Kenya. J. Int. Dev. 20: 380-397

Jaganathan, D., Sheela Immanuel, Sanket J More, Sethuraman Sivakumar, P. 2019. Assessment of livelihood capitals of sweet potato and paddy growers in Karnataka. Indian Res. J. Ext. Edu. 19 (4): $43-48$

Jonathan, G. 2000. Sustainable livelihoods. Int. Soc. Sci. J. 17(4): 77-86.

Lynton, R.P. and Pareek, U. 1990. Training for Development. Vistaar Publications, New Delhi

Mutenje, M. J., Ortmann, G. F., Ferrer, S. R. D., Darroch, M. A. G. 2010. Rural livelihood diversity to manage economic shocks: Evidence from south east Zimbabwe. Agrekon 49: 338-357

Peng, W., Zheng, H., Robinson, B, E., Li, C., Wang, F. 2017. Household livelihood strategy choices, impact factors and environmental consequences in Miyun reservoir watershed, China.
Sustainability, 9: 175- 182

Pereira, T. and Shackleton, S. 2006. Trade in reed-based craft products in rural villages in the Eastern Cape, South Africa. Development Southern Africa 23(4):477-495.

Sayer And Campbell. 2003. The science of sustainable development local livelihoods and the global environment, Cambridge University Press, London, UK

Scoones, I. 1998. Sustainable rural livelihoods: A framework for analysis, IDS, Brighton, UK

Sharma, R, Punit Choudhary and Vikas Tandon. 2019. Initiatives of Krishi Vigyan Kendra (KVK) in doubling of farmers income: A case study of village Sagoon, Jammu. J. Community Mobi. Sus. Dev. 14(3): 379-383

Sheela Immanuel, Jaganathan, D., Sivakumar, P.S., Muthuraj, R. and Prakash, P. 2019. Livelihood assessment of cassava and paddy growing farmers in Tamil Nadu: A Comparative Analysis. Indian J. Pure App. Biosci. 7 (4): 90-98

Sheela Immanuel, Sivakumar, P.S., Prakash, P. and Jaganathan, D. 2017. Livelihood analysis of tuber crops growers in Kerala. J. Root Crops 43(1): 111-115

Swathi Lekshmi, P.S., Venugopalan, R. and Padmini. 2008. Livelihood Analysis using Wealth Ranking Tool of PRA. Indian Res. J. Ext. Edu. 8 (2\&3): 114125

\section{How to cite this article:}

Sheela Immanuel, D. Jaganathan, A.V. V. Koundinya, P. Prakash, P. Sethuraman Sivakumar, H. Kesava Kumar and Muthuraj, R. 2020. Mapping of Livelihood Capitals for Technological Interventions in Elephant Foot Yam and Banana Cultivation in Andhra Pradesh. Int.J.Curr.Microbiol.App.Sci. 9(08): 3686-3696. doi: https://doi.org/10.20546/ijcmas.2020.908.426 